\title{
ANTONIO GRAMSCI, A CULTURA SOCIALISTA E A REVOLUÇÃO RUSSA
}

\author{
Daniela Xavier Haj Mussi
}

é pós-doutoranda em Ciência Política na Universidade de São Paulo, São Paulo, SP, Brasil.

E-mail:<danixhm@gmail.com>

Alvaro Bianchi

é livre-docente do Departamento de Ciência Política da Unicamp, Campinas, SP, Brasil.

E-mail:<albianchi@terra.com.br>

http://dx.doi.org/10.1590/0102-267298/102

A Revolução Russa de 1917 é frequentemente lembrada como um evento político stricto sensu, como investida militar e instauração da ditadura do proletariado pelos bolcheviques. Este artigo reconstrói uma trajetória interpretativa que se choca com esse senso comum, a do escritor italiano Antonio Gramsci no período imediatamente anterior e durante o ano revolucionário russo. Desde a chegada das primeiras notícias da revolução ocorrida na Rússia, é possível encontrar nos artigos de Gramsci a ideia da revolução como "ato de cultura". O jovem jornalista de Turim buscava interpretar os acontecimentos russos sob o ponto de vista da capacidade de expansão de suas ideias-força, como um programa político que era, ao mesmo tempo, uma ruptura com os fundamentos culturais do mundo burguês.

As principais balizas dessa interpretação estão postas pelos escritos reunidos no jornal La Città Futura, publicado poucos dias antes de eclodir a Revolução de fevereiro de 1917 na Rússia, e pelo artigo "La Rivoluzione contro 'Il Capitale'" na edição romana do Avanti!, em 24 de novembro de 1917. Nesse intervalo percebe-se a permanência de 
alguns temas, como a afirmação do caráter socialista e antijacobino da Revolução e de sua dimensão cultural, bem como uma consideração dos eventos na Rússia a partir de uma visão particularmente italiana, mais interessada em fazer deles um exemplo a ser seguido na península do que em interpretá-los.

Nesse momento, o léxico gramsciano é nitidamente neoidealista. Logo após sua eclosão, a Revolução Russa é vista por ele como um "ato proletário", um acontecimento que tem lugar "nas consciências de todos", capaz de promover a "libertação dos espíritos" e a "instauração de uma nova consciência moral”. Também é percebida como um evento de alcance internacional, uma "luz que vem do oriente e irradia o velho mundo ocidental" (Gramsci, 1982, pp. 138-142). Um evento capaz de mudar a correlação de forças internacionais, e sua potência se "reflete sobre os outros proletariados, é a substância de uma vida nova, de 268 uma nova autoridade" (Gramsci, 1982, p. 242).

Ao longo de 1917, embora o léxico permaneça substancialmente o mesmo, uma reconstrução do ritmo do pensamento gramsciano mostra como a influência neoidealista foi gradativamente absorvida em uma visão realista da política influenciada, se não pelo pensamento, ao menos pela ação dos bolcheviques. O ponto de culminância é o artigo de novembro daquele ano, no qual Gramsci esforça-se para compreender o uso da força militar na Revolução como continuidade da ideia de ruptura cultural em sentido amplo que elaborara anteriormente. Ganhava destaque, assim, uma consistente crítica ao reformismo político da maioria da direção do Partito Socialista Italiano (PSI) e a convicção de que era chegada, também na Itália, a hora de agir.

Em fins deste agitado período, neoidealismo e realismo aparecem unidos na análise da política por Gramsci. O resultado é não apenas uma interpretação original da Revolução Russa, a qual guarda valor ainda hoje, mas a emergência de 
uma nova concepção da política que iria resultar naquilo que Gramsci chamaria de "comunismo crítico" (Gramsci, 1984, p. 349).

\section{A guerra e os "ídolos da cultura"}

No final de 1915, Antonio Gramsci passou a atuar como jornalista na seção turinense do PSI, sua primeira experiência orgânica como ativista político-partidário. Gramsci começou sua atividade jornalística como colaborador na coluna "Sotto la Mole"" do jornal Avanti!", sendo esta sua primeira atividade sistemática no interior do movimento socialista. Suas crônicas, quase sempre anônimas ou assinadas com pseudônimos, tratavam de diferentes aspectos da realidade de Turim, escritas como "crônicas da vida cotidiana ou cultural da cidade, mais do que sobre os episódios da vida política e administrativa” (Rapone, 2011, p. 71). Até meados de 1917, porém, esta atividade se daria em "uma posição afastada na vida cotidiana do partido, tanto que nos relatos das assembleias das seções nunca está seu nome" (Rapone, 2011, p. 71).

Os artigos desta época evidenciam um Gramsci "historiador do cotidiano", consciente do contraste de seu texto com a "história dos séculos passados", com a história "grande mestra da vida" (Gramsci, 1980, p. 45). Os limites da atividade de cronista se evidenciavam: esta era uma intervenção de tipo político-cultural imediato e não equivalente

\footnotetext{
1 O nome "Sotto la Mole" fazia referência ao imponente edifício projetado no século XIX por Alessandro Antonelli e construído entre 1863 e 1897 no centro de Turim. Gramsci também gostava de observar que a expressão sotto la mole (que além de "sob a Mole Antonelliana" poderia ser traduzida como "sob o fardo") poderia ser entendida também em um sentido que prescindia do monumento, "como metáfora da condição dos trabalhadores, submetidos ao ônus da opressão capitalista” (Rapone, 2011, p. 62n).

2 O jornal socialista Avanti! era editado em Milão e continha uma página dedicada a Turim, "Cronache Torinesi" [Crônicas de Turim], também conhecida por "edição do Piemonte", cuja equipe de redação era dirigida desde 1902 por Ottavio Pastore (1888-1965).
} 
à atividade disciplinada dos estudos e à pesquisa histórica de fôlego. Entre estes dois estilos, porém, Gramsci abraçou a carreira de jornalista como quem se libertava de uma prisão. Em carta escrita em 1916, para a irmã Grazietta, Gramsci falou com pesar do período anterior à atividade como cronista, momento de isolamento provocado pelos problemas de saúde e financeiros e dedicado exclusivamente aos estudos: "vivi por alguns anos fora do mundo, um pouco no sonho. Deixei que se perdessem, um por um, todos os laços que me uniam ao mundo e aos homens. Vivi totalmente para o cérebro e nada para o coração" (Gramsci, 2009, p. 166). As crônicas representavam, de certa forma, um processo de reconexão com o "mundo e os homens", eram a atividade intelectual vivida fora do "sonho", entrelaçada de maneira apaixonada à vida social (Gramsci, 2009, p. 167).

Em sua atividade jornalística, Gramsci expressava sensibilidade às transformações provocadas pela I Guerra 270 Mundial na vida italiana e, particularmente, em Turim. Inspirava-se na reflexão do intelectual francês Romain Rolland sobre o papel político do "mundo cultural", drasticamente transformado pelo conflito militar nesse período. Rolland criticava "les idoles de La Kultur", intelectuais que "vivem no reino das ideias", desconectados dos processos sociais e que, por este motivo, na guerra "não apenas foram os mais expostos ao contágio bélico, como contribuíram prodigiosamente para difundi-lo" (Rolland, 1953, p. 118; p. 125) ${ }^{3}$. Do isolamento, esses intelectuais passavam ao oportunismo dos que "aderem à concepção que serve melhor" e ao apoio - tímido ou mesmo aberto - ao conflito militar. Inspirado nessa crítica, Gramsci compôs muitas de suas crônicas nos anos 1915 e 1916 para revelar o oportunismo dos representantes da vida intelectual de Turim,

\footnotetext{
3 Gramsci conhecia, desde 1914, o artigo "Les Idoles", de Rolland, quando foi parcialmente traduzido e publicado no jornal Il Grido del Popolo. Este e outros artigos de Rolland seriam publicados alguns anos mais tarde na revista L'Ordine Nuovo.
} 
onde predominavam "os vulgares fraudadores da inteligência” (Gramsci, 1980, p. 34). As crônicas eram, também, uma maneira de construir sua própria subjetividade política. Gramsci retratava um universo cultural decadente em que figuras grotescas se enfileiravam: economistas, filósofos, literatos, clérigos, poetas. Seus artigos se dirigiam especialmente contra os representantes do positivismo na vida intelectual do Piemonte e, como alternativa, projetava a necessidade de fundir, em um único campo teórico, o socialismo e o pensamento neoidealista (Rapone, 2011).

As crônicas da coluna "Sotto la Mole" no jornal Avanti!, de Milão, tinham como objetivo passar em revista crítica uma vida cultural local. Nos artigos publicados no jornal turinense Il Grido del Popolo ${ }^{4}$, entretanto, Gramsci buscou um ponto de vista mais amplo. No artigo "Socialismo e cultura", de 29 de janeiro de 1916, assinado sob o pseudônimo "Alfa Gamma”, Gramsci tratou o tema da cultura em termos gerais e teóricos, como questão de conquista de autonomia individual ("apoderar-se de si") e de busca pela sincronia entre a existência natural e a existência consciente (Gramsci, 1980, p. 99). Apresentada de um ponto de vista histórico, a cultura era proposta como o desenvolvimento problemático da "consciência da igualdade humana" entre "plebeus" e "nobres". Nesse sentido, aparecia como atividade intimamente vinculada aos diferentes momentos em que se deu a elaboração de uma nova "base e razão histórica", seja no surgimento da república democrática, na Antiguidade, seja no surgimento da república burguesa no contexto da Revolução Francesa (Gramsci, 1980).

\footnotetext{
${ }^{4}$ Fundado em 1892, em Turim, o jornal semanário Il Grido del Popolo expressava as concepções do socialismo que se desenvolvia no Piemonte, de traços marcadamente intelectuais e racionalistas. Além de colaborador, Gramsci assumiu o posto de redator-chefe, entre agosto de 1917 e setembro de 1918, o último antes do jornal ser fechado. Essa foi a primeira experiência do jovem socialista sardo à frente de um periódico (Paggi, 1970).
} 
Nesse artigo do Il Grido del Popolo, Gramsci foi além da crítica dos intelectuais turinenses para explorar a questão de modo geral. O jornalista pretendia mostrar ao leitor que a cultura não é resultado de embates restritos aos intelectuais, ou da "educação" oferecida por um grupo social a outro, mas surge e se desenvolve na história como insumo e produto dos próprios conflitos sociais. O "problema supremo da cultura”, afirmou, está justamente neste compor uma dimensão conflitiva onde existe, ao mesmo tempo, como "princípio e limite" dos momentos de luta. Dessa maneira, Gramsci procurava estabelecer o que entendia por "uma justa compreensão do conceito de cultura também em relação ao socialismo" (Gramsci, 1980, p. 102).

Esse empreendimento, ao mesmo tempo político e cultural, ganharia contornos mais precisos com a publicação do jornal La Città Futura, no início de 1917. Já em meados de 1916, depois de quase dois anos da entrada da Itália na guerra, era generalizada a compreensão do "monstruoso preço, em vidas humanas e riquezas, que o país estava pagando" e a postura passiva diante dos acontecimentos parecia, agora, tão nociva quanto o apoio à participação no conflito (Arfè, 1965, p. 228). Assim como os demais partidos socialistas europeus, os socialistas italianos sentiam aumentar as pressões nacionalistas e sofriam com a "flutuação de homens" no partido, dada a dificuldade de afirmar uma política capaz de orientar e engajar seus militantes, cada vez mais numerosos ${ }^{5}$. Em seus artigos, Gramsci caracterizou esse momento de impasse no interior do movimento socialista como uma "reviravolta": "a ação política e administrativa, a eficácia energética [do partido] não está à altura da sua força efetiva” (Gramsci, 1980, p. 352).

\footnotetext{
${ }^{5}$ O PSI era um dos poucos partidos a sustentar a posição firme contra a guerra e o nacionalismo, posição que seria abalada em 1917, no contexto da derrota da Batalha de Caporetto.
} 
Gramsci criticava a política da direção do PSI, que convertia a organização em um "fim em si mesmo", voltada para uma ampliação numérica burocrática do partido, pouco preocupada com as "atitudes" e "sentimentos" de seus ativistas, o que apenas a educação socialista poderia corrigir. Sendo um fim em si mesmo, o partido se revelava "um verdadeiro obstáculo para o alcance do socialismo", incapaz de oferecer respostas às necessidades de "unidade" e "coesão" no interior da massa social "amorfa, flutuante" (Gramsci, 1980, p. 352). A ação direta poderia servir como ponto de "unidade" para as organizações socialistas por um tempo, mas não para sempre. A manutenção de suas fileiras deveria ser realizada por ideias gerais, horizontes distantes, capazes de impor uma disciplina constante e metódica (Gramsci, 1980).

Ao longo de 1916, Gramsci acompanhara o debate aberto no interior da seção socialista de Turim a respeito da fundação de um novo jornal socialista na cidade, que deveria ser um "foco de entusiasmo" (Gramsci, 1980, p. 353), "a voz do partido que a cada dia alcançará espíritos novos, energias novas" (Rapone, 2011, p. 69). Dessa discussão participaram muitos de seus companheiros mais próximos, como Angelo Tasca e Ottavio Pastore, em oposição às posições mais oficiais de dirigentes do PSI, como Giacinto Serrati ${ }^{6}$, que via nesta iniciativa o perigo da perda de controle do partido sobre sua imprensa (Gramsci, 1980). Para Gramsci, rejeitar a criação de um novo jornal era negar que o partido socialista estivesse "diante de uma reviravolta" na sociedade italiana, o que fazia com que o PSI ficasse aquém dos desafios político-administrativos colocados pela expansão do partido (Gramsci, 1980, p. 353).

\footnotetext{
${ }^{6}$ Giacinto Menotti Serrati (1874-1926) era um importante dirigente do PSI, por quem Gramsci nutria muito respeito, mas com quem polemizara muitas vezes. Ativo na Conferência de Zimmerwald, em 1917, Serrati seria responsável por aproximar o partido italiano da Revolução Russa.
} 
Nesse período, a atividade política de Gramsci era bastante exterior às disputas internas do partido e mais voltada para a vida cultural da seção socialista em Turim, onde ministrava conferências (Rapone, 2011, p. 71). Apesar disso, em sua atuação como jornalista, Gramsci demonstrava interesse em participar dos debates partidários, especialmente para combater o economicismo e burocratismo que consumiam o PSI e colocavam seus dirigentes em "um labirinto sem saída" (Gramsci, 1980, p. 352). A criação de um novo periódico não tinha, portanto, fins puramente culturais ou jornalísticos: era uma forma de avançar na elaboração de uma "ideia geral", de um "horizonte capaz de impor disciplina" aos ativistas socialistas (Gramsci, 1980, p. 353).

Esse projeto daria seu primeiro passo nas páginas do opúsculo La Città Futura [A Cidade Futura] (Rapone, 2011, p. 68). Preparado desde fins de 1916 e publicado em fevereiro de 1917 a partir da orientação do comitê regional piemontês da Federazione Giovanile Socialista Italiana [Federação Jovem Socialista Italiana $]^{7}$, o jornal de número único foi integralmente escrito por Gramsci.

A base de Gramsci para composição desse número único revelava seu vínculo com o ambiente operário socialista da capital do Piemonte - especialmente com os jovens. Além disso, foi o resultado da vivência prática na Universidade de Turim, de cultura fortemente positivista e de alguma proximidade com o "debate sobre a crise do marxismo", o qual conhecia ao menos desde 1914 em virtude do contato com o professor Annibale Pastore (Basile, 2014, p. 196; p. 202; D’Orsi; Chiarotto, 2012, pp. 43-44). Essa combinação é importante para compreender as nuances

\footnotetext{
${ }^{7}$ A responsabilidade do jornal foi, inicialmente, assumida pelo jovem ativista socialista de Turim Andrea Viglongo, a quem Gramsci pediu para assumir a tarefa de conduzi-lo para dar-lhe um caráter mais homogêneo e afinado com uma função formativa (Gramsci, 1982).
} 
que caracterizaram os argumentos expostos por Gramsci ao longo dos onze artigos que compuseram La Città Futura.

Folhetim de educação e propaganda socialista dedicado aos jovens, La Città Futura se pretendia um "incentivo e um convite" (Gramsci, 1982, p. 3). Um incentivo a um ato de "independência e libertação" por meio do engajamento no movimento socialista, e um convite para pensar os limites nos quais o socialismo italiano esbarrava (Gramsci, 1982). "O futuro é dos jovens, a história é dos jovens" (Gramsci, 1982, p. 3) - com essas palavras, Gramsci abria o jornal projetando um novo ambiente, no qual pudessem se combinar "energia" e "inteligência", resultando na "mais perfeita e frutífera afirmação" de um movimento socialista renovado (Gramsci, 1982, p. 16). A alternativa à "morte do socialismo" - expressão usada por Gramsci a partir de um artigo do filósofo Benedetto Croce (1993) publicado inicialmente em 1911 na revista La Voce e intitulado "La Morte del Socialismo" - era reencontrar a finalidade organização socialista, "engrossar sempre mais as fileiras e fechá-las" (Gramsci, 1982, p. 16) ${ }^{8}$. O objetivo era converter a situação defensiva na qual o socialismo estava diante de seus críticos em uma oportunidade para atrair e preparar jovens socialistas para um bom combate, capaz de superar o "senso comum", o "terrível aplacador de espíritos" (Gramsci, 1982, pp. 6-7).

O texto de Gramsci nascia como proposição de um combate cultural e político de tipo popular, para "conceder a todos os cidadãos" a "atuação integral da própria personalidade humana” (Gramsci, 1982, p. 11). Com o artigo intitulado "Margini" [Margens], Gramsci apresentou no

8 O filósofo neoidealista Benedetto Croce (1866-1952) foi editor da revista $L a$ Critica e o intelectual de maior destaque na Itália na primeira metade do século XX. Gramsci reconhece explicitamente a influência desse autor afirmando nos Quaderni del carcere que, na época em que redigiu La Città Futura, seu pensamento era "tendencialmente bastante croceano" (Gramsci, 1975, p. 1233). 
La Città Futura a ideia de que, entre as pessoas "comuns", "o esforço feito para conquistar uma verdade" faria desta algo próprio, "mesmo se à nova enunciação não seja agregado nada fundamentalmente novo" (Gramsci, 1982, p. 23). Sua entonação colocava ênfase na vontade que se converte em sacrifício pela descoberta, na rejeição da acepção "determinista da previsão" que reduzia o movimento socialista a uma atitude de passividade (Gramsci, 1982, p. 24). No processo da busca pela verdade, a existência de "modelos", continuava, poderia ser muito útil desde que estes não fossem valorizados em termos absolutos (Gramsci, 1982). Assim como "a lei" e "o esquema", o modelo permitiria a visão da totalidade (Gramsci, 1982). Este não poderia, entretanto, com sua lógica, substituir o movimento concreto do pensamento que conduz à ação e vontade transformadoras.

Sob esse olhar, a crise do socialismo, cuja manifestação se dava na deserção de muitos intelectuais, poderia ser expli276 cada de duas formas. Por um lado, como crise mais geral de "todos os ismos" (positivismo, futurismo, nacionalismo, neoidealismo etc.), concepções engajadas com as quais os intelectuais mantêm relação de exterioridade, "diletante na fé e diletante no saber" (Gramsci, 1982, p. 24). Por outro, como crise específica do socialismo como "visão livresca da vida", na qual esta era "uma avalanche observada sempre à distância” (Gramsci, 1982, p. 25).

A crise do socialismo e do PSI era, para Gramsci, parte de uma crise geral e, ao mesmo tempo, um fenômeno específico. Como parte da crise universal "dos ismos", os socialistas sofriam com a debandada intelectual, já que se expandia entre os intelectuais um ideal exterior de busca pela verdade, algo de "fora" da vida organizada, que os levava a trocar constantemente de partido e de posição política à medida que novos modismos eram lançados. Como crise singular, o socialismo italiano revelava sua incapacidade de entender esta "avalanche", a qual assistia inerte, justificando 
o imobilismo de maneira abstrata por meio da lógica de seu modelo determinista e afirmado como "científico" (Gramsci, 1982). Diante da crise dos intelectuais e da derrota do mito socialista - concluía - apenas a renovação interna do proletariado poderia oferecer uma saída (Gramsci, 1982).

A expansão do proletariado e do movimento socialista em vários países durante a guerra era, para Gramsci, um claro sinal do potencial de renovação da vida popular e, também, de intensificação de sua consciência - o que permitiria o surgimento de um novo mito, criado pela emergência do valor "número", "massa", um novo "mito de universalidade". Essa novidade seria capaz de fazer com que os indivíduos se sentissem "partícipes de algo grandioso que está amadurecendo em cada nação, cada partido, cada seção, cada grupo" (Gramsci, 1982, pp. 26-27). Para ele, a ideia de igualdade - e não a de nacionalidade - permitiria essa renovação aos jovens, sendo Turim um laboratório do "surgimento de uma nova geração livre, sem preconceitos, que romperá a tradição" (Gramsci, 1982, p. 32).

La Città Futura concluía retomando a ideia - surgida ainda antes da guerra nas conversas com outros jovens socialistas de Turim, tais como Angelo Tasca, Umberto Terracini e Palmiro Togliatti (este último menos engajado no movimento socialista até então) - de "fundar uma revista de vida socialista para ser o abrigo das novas energias morais, do novo espírito [...] idealista da nossa juventude" (Gramsci, 1982, p. 34) ${ }^{9}$. Esse jornal de número único, portanto, não era pensado como "mais um ensaio" cultural e filosófico, uma iniciativa puramente intelectual, mas funcionava como um chamado a "quem está convencido que o pensamento e a cultura socialista têm muito que fazer ainda, e

\footnotetext{
9 A menção ao projeto do pré-guerra não deixava de ser uma forma de lembrar os amigos Tasca, Togliatti e Terracini, que nesses dias serviam ao exército italiano no conflito. O projeto só seria concretamente retomado em fins no ano seguinte, com o término da guerra (D'Orsi; Chiarotto, 2012).
} 
que uma nova voz de jovens pode dizer muitas coisas ainda" (Gramsci, 1982, p. 34). Gramsci elaborava, aqui, o projeto de uma revista de pensamento e vida socialista cujo objetivo definia: preparar uma nova geração socialista, capaz de superar o "relativismo" dos intelectuais - tanto os positivistas, como os neoidealistas - e avançar na elaboração de um novo mito para preencher o vazio deixado pela falência do socialismo de bases deterministas e reformistas.

Esse projeto entrava em rota de colisão com o socialismo oficial do partido, cujo núcleo substancial se personificava na figura política de Claudio Treves (Gramsci, 1982; Rapone, 2011) ${ }^{10}$. Para Gramsci, o PSI havia assumido uma posição cômoda diante da vida política do país desde 1914, com a fórmula da neutralidade absoluta com relação à guerra, e com o predomínio no partido do absenteísmo político da posição reformista. No combate a essa posição, Gramsci lançou mão de referências renegadas pela "tradição 278 teórica do socialismo italiano e internacional” (Rapone, 2011, p. 69), tal qual o pensamento neoidealista, que julgava central para compreender a cultura e os dilemas políticos do momento. O uso dessas referências recebeu críticas no interior do partido, mesmo entre os jovens, documentadas nos artigos do jornal da juventude do PSI, L'Avanguardia, no qual Gramsci foi acusado de "intelectualismo" e de ter elaborado "um jornal para iniciados", "dificilmente compreendido pelos leitores proletários” (Rapone, 2011, p. 69n).

No início de 1917, Gramsci considerava central discutir a "preparação cultural necessária para o desenvolvimento da ação socialista" (Rapone, 2011, p. 70). A iniciativa de La Città Futura em Turim era uma forma concreta,

${ }^{10}$ Claudio Treves (1869-1933) era advogado e jornalista em Turim, além de um importante dirigente socialista, figura central na revista Critica Sociale e líder da posição neutralista no interior do PSI. Em 1915, no calor das discussões sobre a participação da Itália na guerra, depois de uma troca de acusações e insultos, chegou a realizar um duelo com Benito Mussolini, no qual ambos se feriram, mas sobreviveram. 
prática, de atuar nesse sentido, buscando mostrar que "a simplicidade da linguagem" informativa não era o aspecto mais importante a ser pensado para favorecer a propaganda socialista, mas sim seu conteúdo formativo (Rapone, 2011, p. 105). Nesse jornal de número único, Gramsci propôs os termos desse conteúdo: pensar a relação entre disciplina e liberdade na organização socialista, redefinir "ordem" como um conceito-chave e agregador, incentivar os jovens a "sair da passividade e indiferença" e a assumir posição de protagonistas da história (Rapone, 2011, p. 68).

Enfrentar a passividade e indiferença significava propor o problema da constituição de uma ordenação social nova, capaz de "substituir o dualismo pela unidade" e superar a falência das "construções sociais utópicas", baseadas em um "futuro harmonicamente coordenado" (Basile, 2014, p. 205). As revoluções burguesas, nos séculos XVIII e XIX, haviam realizado este princípio utópico de maneira universal por meio do liberalismo. $\mathrm{O}$ aspecto paradoxal dessa realização evidenciava, entretanto, o caráter "nada absoluto ou rígido" da história, sendo que a realização plena do Estado suscitava uma nova antítese, o proletariado, e criava a necessidade de novas ideias-força (Basile, 2014, p. 205). Por esse motivo, Gramsci concluía: os socialistas não devem substituir uma ordem por outra. Devem, antes de mais nada, instaurar uma nova ordem em si mesmos (Gramsci, 1982, p. 11).

\section{A Revolução na Rússia}

La Città Futura foi publicado em fevereiro de 1917, momento em que explodia uma Revolução de grandes proporções na Rússia. Apesar da apreensão, do sentimento de que existia a possibilidade de grandes explosões sociais resultantes dos impactos da guerra em toda a Europa, este foi um evento político imprevisto mesmo no ambiente socialista. Não por acaso, a Rússia passara distante das atenções 
políticas de Antonio Gramsci até então. Com a revolução, seu programa para um socialismo criador "de uma ordem em si”, de uma consciência própria, se modificou no ritmo das notícias vinda do Leste.

No início do ano, as informações sobre a revolução eram ainda escassas na Itália e reduziam-se em grande parte à reprodução de artigos publicados pelos jornais de Londres e Paris. Nas páginas do Avanti!, alguns artigos sobre os eventos em São Petersburgo eram assinados por Junior, pseudônimo de Vasilij Vasilevich Suchomlin, exilado russo partidário dos Socialistas Revolucionários em seu país natal. Para suprir os socialistas italianos de informações confiáveis, a direção do PSI encaminhou um telegrama ao deputado italiano Oddino Morgari, pedindo-lhe que fosse até Petrogrado e entrasse em contato com os revolucionários russos. Essa viagem fracassou e Morgari retornou à Itália em julho ${ }^{11}$.

Apesar das dificuldades em interpretar os eventos que 280 derrubaram o czarismo russo e instauraram um Governo Provisório, os primeiros argumentos de Gramsci sobre o assunto mostram seu esforço por aproximar a Revolução Russa da ideia de criação de uma "nova ordem"12. Pelos artigos escritos entre abril e maio de 1917, nota-se que ele tinha muito interesse em interpretar os acontecimentos do Leste para convertê-los em lições possíveis aos italianos. De acordo com Gramsci, sabia-se que a revolução havia sido "feita pelos proletários" e que existia "um comitê de delegados operários que controla o trabalho dos entes administrativos" (Gramsci, 1982, p. 138). Mas não era isso que dava à Revolução um caráter proletário. Para isso, era necessário investigar os "fatores espirituais", ou seja, verificar se

\footnotetext{
11 O comentário de Gramsci nas páginas do Avanti! no dia 20 de abril sobre a repercussão da viagem de Morgari é seu primeiro artigo sobre a Revolução Russa "Morgari in Russia" [Morgari na Rússia] (Gramsci, 1982).

12 Trata-se de um artigo de abril de 1917, intitulado "Note sulla rivoluzione russa" [Notas sobre a Revolução Russa], publicado no jornal Il Grido del Popolo.
} 
a Revolução era também um "fenômeno de costumes", um "fato moral" (Gramsci, 1982, p. 138).

Esse programa de pesquisa - continuidade de suas elaborações anteriores - exigia que fosse investigada a capacidade da revolução em promover uma nova cultura. A revolução não deveria ser considerada apenas como um fato, algo mecânico, mas também como ato proletário em direção ao socialismo. Na diferença entre ato e fato é possível identificar uma chave de leitura neoidealista, inspirada em Giovanni Gentile (1937), que alguns anos antes havia desenvolvido a noção de fato espiritual, objeto do conhecimento, só conhecido quando a objetividade se dissolve na ação real do sujeito do conhecimento. A subjetividade humana, aqui, determinava a natureza do fato ${ }^{13}$. O uso que Gramsci fez da noção de ato proletário servia, desse modo, para destacar a intervenção do proletariado na história como ação de um espírito superior a todos os interesses particulares.

Como fato moral e ato proletário, a revolução na Rússia era interpretada por Gramsci como de natureza essencialmente antijacobina. Ela não era a expressão de interesses particularistas de classe, nem um "fato violento", como havia sido a revolução burguesa na França, muito menos se assemelhava a "um regime autoritário que substitui outro regime autoritário" (Gramsci, 1982, p. 138). Para o jovem jornalista, a nova revolução havia "destruído o autoritarismo e o substituído pelo sufrágio universal, estendendo-o até mesmo às mulheres" e, dessa maneira, instituído a "liberdade" e dado lugar para "a voz livre da consciência universal” (Gramsci, 1982, p. 139). A revolução era, aqui, um ato do espírito;

13 "O ato, se não converter-se em um fato, se deve ser compreendido em sua natureza atual, o ato puro, só pode ser pensamento. O fato é a negação do pensamento porque o próprio pensamento cria seu outro, a natureza. Apenas do ato se desce ao fato, se está fora do pensamento, no mundo da natureza. Não existem fatos espirituais, mas atos; na verdade, não existe se não o ato do espírito" (Gentile, 1937, p. 29). 
ela está na consciência de todos e se transformará em decisão irrevogável apenas possa expressar-se em um ambiente de liberdade espiritual absoluta, sem o qual o sufrágio seria pervertido pela intervenção da polícia e pela ameaça da forca ou do exílio. O proletariado industrial já está preparado para essa passagem mesmo culturalmente; o proletariado agrícola, que conhece as formas tradicionais do comunismo comunal, está também preparado para a passagem a uma nova forma de sociedade (Gramsci, 1982, p. 139).

O paralelo entre a Revolução Francesa de 1789 e a Revolução Russa que ocorria em 1917 era muito comum na imprensa da época e não se tratava de uma invenção de Gramsci. Na imprensa socialista, já no dia 19 de março, Il Grido del Popolo havia publicado um editorial, assinado por 282 Nar, pseudônimo de Gaetano Polverelli, intitulado "L'89 di Russia” [O 1789 da Rússia]. A analogia com a França também havia sido retomada logo em seguida, em 23 de março, pelo deputado e dirigente socialista Filippo Turati, em discurso na Câmara de Deputados:

a Revolução Russa, cujo acontecimento parece recordar formidavelmente a revolução da França, de fato supera de uma só vez as fases de [17]89 e [17]93, abate todos os obstáculos e triunfa sem retorno e represálias possíveis (Turati, 1917, p. 13377).

Antes mesmo de 1917, a analogia se tornara comum na Rússia e no movimento socialista internacional em virtude dos levantes de 1905. A novidade introduzida por Gramsci nesse paralelo histórico estava na recusa do jacobinismo. Além da interpretação antijacobina da revolução promovida 
por Gaetano Salvemini (1905) ${ }^{14}$, Georges Sorel (1847-1922) e Benedetto Croce também eram fontes do antijacobinismo de Gramsci. A primeira delas fora a difusão, na Itália, da obra de Georges Sorel, Réflexions sur la violence [Reflexões sobre a violência] (2013), na qual o teórico do sindicalismo revolucionário recusava as "abominações" das revoluções burguesas e, em especial, os acontecimentos de $1793^{15}$. Gramsci fez uma referência explícita a essa obra em um artigo de 30 de outubro de 1916 (Gramsci, 1980). As ideias de Sorel também se faziam sentir na obra de Benedetto Croce, o qual, em Cultura e vita morale [Cultura e vida moral], publicado em 1914, identificara o jacobinismo com a "mentalidade maçônica", ou seja, com uma maneira de pensar que simplifica tudo "em nome da razão, da liberdade, da humanidade, da fraternidade, da tolerância", procedendo por meio de abstrações e "classificando fatos e homens por sinais exteriores e fórmulas" (Croce, 1993, p. 143). Gramsci conhecia muito bem esse livro do filósofo napolitano - a

14 A interpretação de Gramsci da cultura no contexto da revolução na França possuía forte identidade com as pesquisas de Gaetano Salvemini (1873-1957), intelectual neoidealista, socialista, de origem meridional e radicado em Florença. Este concebia as grandes transformações políticas do final do século XVIII na França como resultado da interferência das grandes massas na política em um momento histórico, processo este que poderia ter resultados heróicos ou desastrosos, a depender da orientação seguida pela "multidão exasperada e frenética" (Salvemini, 1905, p. 138). Salvemini buscava se distanciar dos revolucionários franceses, girondinos e jacobinos, para mostrar que nenhum dos dois grupos fora responsável por sistematizar, isoladamente, o sucesso ou o fracasso das lutas políticas. A revolução, aqui, era pensada como obra intelectual em sentido amplo, realizada em grande medida pelos "filósofos pré-revolucionários", responsáveis por refutar "as velhas regras no campo da vida prática" e abrir um espaço possível por onde as "massas incultas" poderiam caminhar em um contexto de crise das classes dominantes (Salvemini, 1905, p. 354).

15 "Temos o direito de concluir, então, que não se pode confundir as violências sindicais exercidas ao longo das greves por proletários que desejam a derrubada do Estado com esses atos de selvageria que a superstição do Estado sugeriu aos revolucionários de 1793 quando tiveram o poder nas mãos e puderam oprimir os vencidos de acordo com os princípios que haviam recebido da Igreja e da realeza. Temos o direito de esperar que uma revolução social levada a cabo pelo sindicatos pelos puros sindicalistas não será manchada pelas abominações que marcaram as revoluções burguesas" (Sorel, 2013, p. 93). 
ponto de extrair e incluir uma passagem dele em La Città Futura - e tomaria o título como inspiração, em 1918, para a proposta de criação de um Clube de Vida Moral em Turim, com vistas a "habituar os jovens que aderem ao movimento político e econômico socialista à discussão desinteressada dos problemas éticos e sociais" (Gramsci, 2009, p. 177).

Essas eram as referências intelectuais que estruturavam, nos primeiros meses de 1917, a interpretação antijacobina de Gramsci a respeito da Revolução Russa. Retomando certas ideias que discutira nos meses anteriores em relação ao positivismo - e seguindo mais de perto o argumento de Sorel - o jornalista socialista afirmava que o jacobinismo era um fenômeno puramente burguês, pois estava destinado a realizar os interesses particulares desta classe (Sorel, 2013). Como ato proletário, portanto, a revolução na Rússia se distanciava da experiência francesa. Mais do que interpretar de maneira totalmente fiel os acontecimentos de 284 Petrogrado, Gramsci desenvolvia o programa político que havia anunciado como problema nas reflexões sobre a cultura, em 1916, e como necessidade para a reorganização da juventude socialista no início de 1917. Sua interpretação da revolução visava mostrar a impossibilidade de avanço de uma revolução operária sem a ruptura definitiva com o modelo político jacobino, ou seja, com o mundo político e cultural burguês.

O antijacobinismo como chave de leitura da Revolução Russa seria mais uma vez usado por Gramsci no artigo "Un po' di Russia” [Um pouco da Rússia], publicado em 15 de maio de 1917, na contraposição da ação de uma "maioria efetiva" aos "abusos de uma minoria facciosa e jacobina" (Sorel, 2013, p. 280). Foi também nessa chave que o jornalista socialista interpretou as forças dirigentes da revolução no importante artigo publicado em 28 de julho de 1917, "I massimalisti russi" [Os maximalistas russos]. Expressando o apoio que os bolcheviques encontravam 
entre os socialistas, Gramsci afirmou que os maximalistas eram "a continuidade da revolução, o ritmo da revolução, por isso, a própria revolução" (Gramsci, 1982, p. 265). Os bolcheviques expressavam o novo "estado de ânimo" sobre o qual Gramsci falara em 1916, eram a encarnação da "ideia-limite do socialismo" que não comportava um compromisso com o passado milenar (Gramsci, 1982).

Gramsci defendeu os maximalistas das campanhas de difamação e calúnia promovidas na imprensa comercial em todos os países ocidentais e afirmou seu papel político como imprescindível para que a revolução não se interrompesse no país (Gramsci, 1982). Preocupado em intervir para fortalecer uma posição socialista verdadeiramente autônoma, no início de agosto, Gramsci relatou de maneira entusiasmada em Il Grido del Popolo dois grandes comícios que reuniram dezenas de milhares de pessoas em Turim para receber uma delegação russa que percorria a Itália para falar sobre a "novidade" da revolução (Gramsci, 1982) ${ }^{16}$. Essas atividades promoviam, em sua opinião, um verdadeiro "espetáculo das forças proletárias e socialistas solidárias com a Rússia revolucionária” (Gramsci, 1982, p. 274). A visita da delegação russa à Itália se dava em um momento de importante crise do Governo Provisório - incapaz de estabilizar-se, em um contexto de protestos de massa contra as novas ofensivas militares russas - e da escalada de repressão aos bolcheviques que fez com que Lenin fugisse para a Finlândia para poder continuar atuando politicamente (Carr, 1964). O jornal La Stampa, por sua vez, noticiava a fuga de Lenin ("que a esta altura está na Alemanha”) como uma confirmação da

\footnotetext{
${ }^{16}$ Apenas em agosto, com a viagem à Itália de uma delegação representando os sovietes russos, da qual faziam parte Iosif Goldemberg e Aleksandr Smirnov, os socialistas italianos puderam entrar em contato direto com os revolucionários russos. No Avanti!, Gramsci resumiu os discursos de Goldenberg e Smirnov em uma manifestação que ocorreu em Turim no dia 13 de agosto, Il compito della rivoluzione russa [A tarefa da revolução russa] (Cf. Gramsci, 1982). Sobre a calorosa recepção aos delegados dos sovietes em Turim, ver Spriano (1972).
} 
especulação sobre a infiltração alemã entre os extremistas da revolução, comemorando a "perda irreparável" de sua autoridade diante das massas russas (KERENSKI..., 1917).

Na segunda metade de 1917, como redator e, logo em seguida, diretor do jornal Il Grido del Popolo, a intervenção de Gramsci se voltou contra a interrupção da revolução, convicto da necessidade de que esta avançasse e produzisse uma nova racionalidade e subjetividade históricas. A maneira que encontrou para fazer isso foi a defesa da Revolução Russa como um ato antijacobino, como processo no qual todas as ideias poderiam ter lugar e em que os mais diversos grupos políticos poderiam ser criados em torno delas. Sua defesa da posição maximalista aparecia como defesa do "último elo lógico do devir revolucionário" (Gramsci, 1982, p. 265). A revolução era, portanto, um fenômeno eminentemente inclusivo, no qual a direção dos maximalistas sobre os demais grupos era resultado de sua maior capacidade de 286 afirmação cultural.

Em agosto de 1917, Gramsci insistia na semelhança entre o que entendia por cultura e a revolução em curso. A revolução representava a "substituição de valores, de pessoas, de categorias, de classes" (Gramsci, 1982, p. 282). A essa altura, já havia concentrado seu interesse na elaboração programático-partidária, mas o problema da cultura se mantinha como elo de ligação com sua origem como cronista corrosivo da vida cotidiana. A crítica ao jacobinismo, entretanto, mantinha seu lugar. Para Gramsci, a ausência de jacobinismo teria impedido que os extremistas fossem "afogados no sangue", que estes não tivessem na Rússia o mesmo destino de Gracchus Babeuf na França. A revolução como ato proletário era o que permitia aos bolcheviques converterem seu pensamento "em força operante na história", a força vista aqui com resultado de um movimento amplo das consciências, o que seria impossível do ponto de vista burguês-jacobino. Apenas a revolução projetada como ato 
proletário seria capaz de efetivar-se nas consciências, "encorajá-las" e "conquistá-las", tal como os partidários de Lenin faziam. Finalmente, a seu ver, surgira um novo "estado de ânimo" capaz de encarnar-se em uma "multidão de indivíduos" e as ideias haviam voltado a produzir "frutos no terreno da ação" (Gramsci, 1982, pp. 266-267) ${ }^{17}$.

$\mathrm{O}$ antijacobinismo de Gramsci, portanto, guardava uma distância em relação aos intelectuais neoidealistas italianos e ao sindicalismo revolucionário. Diferente destes, Gramsci defendia a Rússia revolucionária como encarnação viva e efetiva de um novo estado de ânimo histórico, como "uma contínua mudança no bloco amorfo do povo", em que "novas energias são suscitadas" e "novas ideias-força propagadas". Diferente do modelo político burguês, os sujeitos dessa revolução eram indivíduos, ao mesmo tempo, autônomos e capazes de pensar e agir sem se comportar como "minorias despóticas" (Gramsci, 1982, p. 267). Em 15 setembro de 1917, quando os bolcheviques enfrentaram de maneira vitoriosa as tropas lideradas pelo general Lavr Kornilov, Gramsci referiu-se, mais uma vez, a uma "revolução que ocorreu nas consciências" (Gramsci, 1982, p. 342). O uso da força para resistir à ofensiva militar contrarrevolucionária tinha natureza distinta do uso da força burguesa, nascia do movimento contínuo das consciências. Por isso, também, em 28 de setembro, Gramsci definiu Lenin como "o agitador das consciências, o despertador das almas dormentes" (Gramsci, 1982, p. 359).

\section{Semanas que parecem anos}

Em 7 de novembro, os bolcheviques assumiram o controle dos pontos estratégicos de Petrogrado e prenderam

\footnotetext{
17 Gramsci retomaria, em setembro de 1917, a ideia de que Lenin e os bolcheviques representavam o futuro da revolução: "Kerenski representa a fatalidade histórica, enquanto Lenin representa o devir socialista e nós estamos com ele, com toda nossa alma" (Gramsci, 1982, p. 285).
} 
membros do Governo Provisório, enquanto outros, como Kerenski, fugiam (Carr, 1964). Na mesma noite, "o poder foi passado para as mãos do Soviet dos Deputados dos Operários, Soldados e Camponeses". Nos dias seguintes, foram adotados decretos referentes à paz e distribuição de terras, e criou-se o Conselho de Comissários do Povo, o "primeiro governo dos operários e camponeses" (Carr, 1964, p. 100). As dificuldades e desafios políticos nesse novo contexto eram enormes e o impacto da tomada do poder pelos bolcheviques na esfera internacional era gigantesco.

$\mathrm{Na}$ Itália, esses eventos foram sentidos de maneira ainda mais intensa, em virtude da importante derrota militar para os alemães e o Império austro-húngaro, que ocorrera na semana anterior à revolução, na batalha de Caporetto (D’Orsi, 1985). As perdas humanas foram muitas, assim como o número de prisioneiros e feridos, mas a principal derrota desse confronto foi política, com uma grande retirada do exército italiano da região do Rio Piave, o afastamento do célebre general Luigi Cadorna de suas funções e a desmoralização do governo italiano e da campanha interventista.

Quando a notícia da tomada do poder pelos bolcheviques chegou à Itália, portanto, esta encontrou um ambiente político devastado por uma derrota militar de grandes proporções e com sentimento de insatisfação muito difundido. A imprensa, para não falar da derrota, comemorava a "retirada perfeita" das tropas italianas, sua recomposição e o heroísmo dos soldados. O governo havia lançado mais um decreto de convocação às armas dos italianos nascidos entre 1874 e 1899, mas a continuidade do conflito não conseguia se sustentar na opinião pública como antes. Poucos dias depois, em 9 de novembro, Cadorna foi substituído. As notícias do "grave conflito entre o Estado-Maior russo e os sovietes" inundavam a imprensa, estabelecendo 
um incontrolável senso de comparação entre o que se passava nos dois países.

Para Gramsci, essas foram semanas de grande mudança. Desde fins de outubro, o jovem jornalista sardo ocupava a posição de secretário da Comissão Executiva Provisória da seção socialista de Turim e de redator-chefe do Il Grido del Popolo, em virtude da prisão de Maria Giudice depois dos protestos massivos de agosto que tomaram a Itália, exigindo pão e o fim da guerra (Gramsci, 2009). Em suas cartas deste período, Gramsci relatou o esforço por atuar como redator, para transformar o jornal em um veículo capaz de oferecer um "tratamento dos problemas concretos do programa" do partido e "fortalecer uma consciência unitária do proletariado italiano" (Gramsci, 2009, p. 170; p. 173).

Desde o início de novembro, a censura sobre os jornais socialistas aumentara sensivelmente (Cortesi, 1969). Ao comentar a censura parcial ou total a uma série de artigos sobre a grave crise militar italiana, publicados na página de Turim do Avanti! e do Il Grido del Popolo, Gramsci ironizou o papel do censor em eliminar da opinião pública apenas a posição socialista e, em especial, aquela elaborada na capital do Piemonte (Gramsci, 1982). O jovem dirigente socialista notava que a censura se intensificava justamente no momento em que as classes sociais e o governo reconheciam a necessidade de elaboração de "novas fórmulas" políticas capazes de substituir a decadência de ideias como "todos às armas" e "por um fronte único militar", difundidas no início da guerra (Gramsci, 1982, p. 428).

Gramsci percebia aquelas como "semanas que parecem dois anos", dada a intensidade com que os acontecimentos internacionais e nacionais impactavam a Itália, com a falência sucessiva das fórmulas políticas que as classes dominantes tentavam implementar em resposta à crise, tais como "pela resistência interna" e "pela concórdia nacional" (Gramsci, 1982, p. 429). Em 10 de novembro, a imprensa noticiou 
o "golpe de Estado na Rússia", com a "sede do palácio de inverno ocupada pelos maximalistas", o "apossamento do poder pelos sovietes", a fuga de Kerenski e a prisão de muitos ministros de seu governo (IL NUOVO..., 1917, p. 1). Em artigo publicado duas semanas depois, em 24 de novembro, Gramsci relembrou o artigo do Il Grido del Popolo, de meses antes, no qual afirmara que a revolução não poderia "se interromper com a fase Kerenski" (Gramsci, 1982, p. 450). Em outro artigo da mesma edição, comentou o sentimento de inquietude e incerteza que predominava no movimento socialista italiano em relação à Revolução Russa, do "tumulto de intenções ainda incertas que se exprimem genericamente" do qual ele próprio tomava parte (Gramsci, 1982, p. 452).

A revolução no Leste era vivida como uma espécie de abalo sísmico, um "tumulto" que não limitava à "mudança da fórmula política", mas se realizava como processo de 290 "interiorização, de intensificação da vida moral" (Gramsci, 1982, p. 453). Isso levava Gramsci, mais uma vez, à conclusão de que os socialistas italianos eram revolucionários na ação, mas reformistas no pensamento. A ação radical, porém, deveria encontrar o pensamento revolucionário, desprendido de qualquer reformismo (Gramsci, 1982). A revolução aguçava um sentimento de inquietude que nascera nos anos da guerra e se expressara na preocupação com a cultura, com a reforma do pensamento e dos métodos de ação socialistas (Gramsci, 1982).

Em 12 de novembro, a fração parlamentar do Partido Socialista, liderada por Filippo Turati e Claudio Treves, sob a pressão nacionalista depois de Caporetto, passou a assumir uma atitude explicitamente nacionalista e passado a advogar a defesa da pátria, distanciando-se do neutralismo dos anos precedentes. Nas páginas de Critica Sociale, Turati e Treves publicaram o artigo, em novembro daquele ano, no qual afirmavam a necessidade de o proletariado defender a 
pátria na hora do perigo (Treves; Turati, 1917; ver o comentário de Spriano, 1972, p. 451). A fração intransigente-revolucionária do partido socialista também se organizou para fazer frente à nova situação. Nos primeiros dias de novembro, dirigentes da fração convocaram uma reunião secreta em Firenze, para discutir "a orientação futura de nosso partido" (Spriano, 1972, p. 454). Gramsci, como visto, assumiu funções importantes na seção local do partido e participou do encontro representando Turim (Spriano, 1972). Na reunião, o diretor de Il Grido del Popolo alinhou-se com aqueles, como Amadeo Bordiga, que achavam que era necessário agir, enquanto Serrati e outros se pronunciaram pela manutenção da antiga tática neutralista. A reunião terminou reafirmando os princípios do internacionalismo revolucionário e a oposição à guerra, mas sem nenhuma orientação a respeito do que fazer (Spriano, 1972).

Gramsci retornou a Turim convencido de que era o momento de agir e escreveu mais uma vez a respeito dos acontecimentos na Rússia no artigo intitulado "La rivoluzione contro 'Il Capitale"” [A revolução contra "O Capital”]. "A revolução dos bolcheviques inseriu-se, definitivamente, na revolução geral do povo russo”, começou (Gramsci, 1982, p. 513). Depois de terem impedido que a revolução se estagnasse, os partidários de Lenin haviam chegado ao poder em condições de estabelecer "sua ditadura" e elaborar as "formas socialistas às quais a revolução deverá finalmente adequar-se, para continuar a desenvolver-se harmonicamente, sem grandes choques" (Gramsci, 1982, p. 513).

Até então, a palavra ditadura não fazia parte do léxico de seus artigos, mas mesmo aqui é possível ver seu esforço por interpretar o uso da força em um quadro mais geral, "cultural" em sentido amplo. Para Gramsci, a "revolução dos bolcheviques se baseava mais em ideologias do que em fatos" (Gramsci, 1982, p. 513). Justamente por isso, afirmou, não fora na letra de Marx que os maximalistas russos 
teriam encontrado um guia para a ação. Na Rússia, escrevia, O Capital era "o livro dos burgueses mais do que dos operários” (Gramsci, 1982, p. 513). Gramsci referia-se ao Prefácio de 1867, no qual Marx afirmara que as nações com maior desenvolvimento capitalista mostravam o caminho a ser percorrido pelas demais e não poderia saltar "fases naturais" 18 . Tanto o determinismo reformista predominante no socialismo italiano como o marxismo legal russo tomavam como base essa elaboração e a usavam para defender a formação de uma burguesia e de uma sociedade industrial plenamente desenvolvida antes de qualquer transformação socialista na Rússia. Os bolcheviques, segundo Gramsci, "não são marxistas" pois, embora não renegassem "o pensamento imanente, vivificador" de Marx, "renegam algumas afirmações do Capital”, ou seja, recusam "uma doutrinazinha exterior, de afirmações dogmáticas indiscutíveis" (Gramsci, 1982, pp. 513-514).

292 O raciocínio de Gramsci sobre o reformismo se estendia para pensar não apenas as organizações da classe trabalhadora. Gramsci via o reformismo como um momento do desenvolvimento da cultura e da política, vinculado ao avanço da conformação do capitalismo nos diversos países. No caso italiano, porém, constatava que a burguesia estava atrasada em relação ao proletariado. Durante décadas os trabalhadores italianos haviam desenvolvido uma concepção política própria, ainda que limitada, e que se materializava no reformismo. A burguesia local, por sua vez, apenas depois da entrada da Itália na guerra, em 1914, fora capaz

\footnotetext{
18 Segundo Marx, "não se trata do grau maior ou menor de desenvolvimento dos antagonismos sociais decorrentes das leis naturais da produção capitalista. Trata-se dessas próprias leis, dessas tendências que atuam e se impõem com férrea necessidade. O país industrialmente mais desenvolvido não faz mais do que mostrar ao menos desenvolvido a imagem de seu próprio futuro" (Marx, 2013, p. 78). E mais adiante afirmava: "Ainda que uma sociedade tenha descoberto a lei natural de seu desenvolvimento [...], ela não pode saltar suas fases naturais de desenvolvimento, nem suprimi-las por decreto. Mas pode, sim, abreviar e mitigar as dores do parto" (Marx, 2013, p. 79).
} 
de dar os primeiros passos no sentido de uma concepção econômica própria, da formação da "individualidade de classe", que se materializava em uma forma de "reformismo burguês", o nacionalismo econômico. Em um plano mais geral, para Gramsci, esses dois programas político-econômicos - reformismo e nacionalismo - eram equivalentes, dada sua "aparência revolucionária" e seu conteúdo conservador (Gramsci, 1982, p. 454).

Depois da Revolução Russa, entretanto, o proletariado italiano - assim como o russo - tinha a oportunidade de avançar e atingir a maturidade de pensamento no contato com o socialismo revolucionário (Gramsci, 1982). De um ponto de vista histórico, continuava, a este novo momento do pensamento das classes trabalhadoras, a burguesia deveria opor a "doutrina liberal" desenvolvida e operante em países como Inglaterra e Estados Unidos (Gramsci, 1982). Contudo, na Itália - como na Rússia - esta doutrina era simplesmente incapaz de se desenvolver. Por esse motivo, a principal lição da revolução na Rússia era a de que o proletariado seria capaz de pular o momento revolucionário burguês e mesmo realizar seus princípios, particularmente o da liberdade.

Em dezembro, portanto, Gramsci afirmou o caráter expansivo da revolução bolchevique em termos históricos e geográficos. Os "maximalistas" apropriaram-se do poder para evitar que a revolução estagnasse e agora se dedicavam à elaboração das formas socialistas pelas quais a revolução poderia se adaptar para continuar a se desenvolver. A interpretação de Gramsci sobre Marx tinha inspiração croceana, procurava aquilo que era morto e vivo em seu pensamento (Gramsci, 1982). Porém, diferente do que pensava o filósofo napolitano, para Gramsci, a superação do "cânone" marxista - ou de suas "incrustações positivistas e naturalistas" - não era uma atitude abstrata, puramente intelectual (Gramsci, 1982, p. 514). 
Gramsci considerava o marxismo um bom "cânone de crítica histórica" para períodos de "normalidade" do desenvolvimento do capitalismo, nos quais se poderia observar e fazer previsões a respeito do avanço do "caos-povo para uma ordem de pensamento, sempre mais consciente da própria força” (Gramsci, 1982, pp. 513-514). A guerra, contudo, marcara um ponto de virada no "despertar das vontades", em particular na Rússia, onde o "sofrimento acumulado" se convertera em um uníssono, mecanicamente e espiritualmente Gramsci, 1982, p. 415). Nesse novo contexto de lutas, a "pregação socialista" deveria adquirir um novo papel, projetando a experiência do povo russo internacionalmente, criando uma "vontade social" e consciência novas, dispostas a questionar a necessidade de "esperar" o desenvolvimento da burguesia. Mesmo sendo o pensamento de uma minoria, essa pregação poderia se converter no "meio" pelo qual o proletariado vivenciaria uma nova e inesperada experiência 294 (Gramsci, 1982).

Nesse último artigo de 1917 sobre o tema, escrito com poucos meses de distância em relação às primeiras intervenções sobre a Revolução Russa, é notável o esforço de Gramsci por captar o significado mais geral dos acontecimentos, especialmente no que se referia ao papel dos bolcheviques. As primeiras intervenções eram marcadas pela ideia de continuidade entre o Governo Provisório russo e os maximalistas, mas, ao final do ano, Gramsci falou de maneira incisiva sobre a necessidade de levar a cabo a crítica do reformismo, inclusive por meio da força. Para essa mudança de abordagem, contribuía não apenas a conquista do poder pelos bolcheviques em outubro-novembro, mas também o balanço da atitude dos dirigentes socialistas italianos diante dos grandes protestos contra a guerra de agosto, especialmente em Turim. No fim de 1917, portanto, Gramsci sobrepunha de maneira sutil as duas realidades nacionais, em uma comparação anunciada na ideia 
de internacionalização da propaganda socialista e da consciência das massas proletárias nos diferentes países.

\section{Conclusões}

Fundado em 1892, em Turim, o jornal semanário Il Grido del Popolo expressava as concepções do socialismo que se desenvolvia no Piemonte, de traços marcadamente intelectuais e racionalistas. Gramsci foi seu último redator-chefe, entre agosto de 1917 e setembro de 1918, e esta foi sua primeira experiência à frente de um periódico (Paggi, 1970). Em outubro de 1918, um ano depois da tomada do poder pelos bolcheviques na Rússia, Il Grido del Popolo anunciaria o encerramento de suas atividades para dar lugar à publicação de uma edição piemontesa do Avanti! - que se somava às edições romana e milanesa - na qual Gramsci passaria a atuar como jornalista. A ideia era manter, no novo jornal, o formato de "crônica" das questões envolvendo a cidade de Turim e toda a região do Piemonte, buscando uma ampliação do enraizamento e organização local do PSI (Gramsci, 2009). Esse período coincidia com o fim da guerra e o começo do retorno dos soldados do front, dentre eles muitos socialistas (Fiori, 2003).

Com a recomposição da seção socialista de Turim, Gramsci assumiu então uma posição marginal em relação à direção do partido, dedicando-se integralmente a atividades de propaganda. Suas críticas às posições reformistas do PSI eram expressivas, mas não significavam ainda a disposição para a organização ou participação ativa em alguma tendência ou fração interna (Terracini, 1976, p. 251). Sua atuação se voltou toda para a integração e desenvolvimento político na base da organização, especialmente aquela operária. O objetivo era educá-la de maneira paciente e dedicada para que esta pudesse compreender e reagir diante dos equívocos da política reformista da organização. Foi nesse 
contexto que, tanto a reflexão sobre os intelectuais como aquela sobre os limites do Estado, ganhariam força.

O ano 1917 esteve longe de representar, portanto, o ponto final da análise de Gramsci sobre a revolução na Rússia ou a crise do socialismo na Itália. Nos anos seguintes, muitas das interpretações formuladas no período aqui investigado seriam retomadas, reelaboradas ou mesmo descartadas por Gramsci. A reconstrução das ideias do jovem jornalista socialista no período 1916-1917, portanto, não alcança posições definitivas a respeito da sua interpretação sobre a Revolução Russa e as possibilidades revolucionárias na Itália.

Os anos de 1916 e 1917 marcaram o início da atividade de Gramsci como jornalista da imprensa socialista italiana, período em que este buscou compatibilizar sua formação intelectual e erudição e a escrita de artigos voltados para um público ativista e partidário. Um período que coincidiu, além disso, com o aprofundamento da crise humanitária 296 gerada pela I Guerra Mundial e com as grandes esperanças projetadas pela revolução em um país atrasado economicamente no interior da Europa. Até fins de 1916, a cultura e a crítica dos intelectuais deram o tom aos artigos de Gramsci. Tratava-se de reconstruir o "interior" do socialismo italiano, reencontrar seu "estado de ânimo", iniciativa que se cristaliza de maneira programática no opúsculo La Città Futura. A partir de março de 1917, porém, este programa é paulatinamente deslocado, passa a dar lugar a uma tentativa de interpretar a renovação "espiritual" socialista com base na experiência revolucionária em curso. As ferramentas intelectuais de que Gramsci dispunha até então para armar este projeto de reforma cultural em seu partido passam a ser usadas para construir uma nova intervenção analítica a respeito dos grandes acontecimentos.

Ao final desse período - especialmente depois da tomada do poder pelos bolcheviques na Rússia - essas "ferramentas" passam por uma espécie de reforma antirreformista. 
A cultura é aproximada da revolução não mais pela lógica da precedência temporal, mas como aspecto interno, fonte de legitimidade que se renova na experiência política das massas. De forma tímida, mas explícita, Gramsci introduz, em sua interpretação "culturalista" (ou "culturista", termo usado na época), o elemento da força militar, até então considerado impróprio em um "ato de vontade" proletário. Cultura e revolução se encontram pela primeira vez em seus escritos e formam a base para o par conceitual "consenso-força” que o acompanharia até os anos 1930, em seus últimos escritos como prisioneiro do fascismo.

\section{Daniela Xavier Haj Mussi}

é pós-doutoranda em Ciência Política pela USP.

\section{Alvaro Bianchi}

é livre-docente do Departamento de Ciência Política da Unicamp.

\section{Bibliografia}

ARFÈ, G. 1965. Storia del socialismo italiano: 1892-1926. Torino:

Giulio Einaudi.

BASILE, L. 2014. "Caro Maestro", "Eccezionale studente": sul rapporto di

A. Gramsci con V. A. Pastore. Ipotesi e Riscontri. Giornale Critico della Filosofia Italiana, v. 10, n. 1, p.187-211.

CARR, E. H. 1964. La rivoluzione bolscevica 1917-1923. Torino:

Giulio Einaudi.

CORTESI, L. 1969. Il socialismo italiano tra riforme e rivoluzione: dibatti congressuali del PSI 1892-1921. Bari: Laterza.

CROCE, B. 1993 [1914]. Cultura e vita morale. Napoli: Bibliopolis. . 1915. Frammenti di etica. La Critica: Rivista di Letteratura, Storia e Filosofia, Napoli, v. 13, pp. 153-155.

CUOCO, V. 1913 [1901]. Saggio storico sulla rivoluzione napoletana del 1899 seguito dal rapporto al Cittadino Carnot di Francesco Lomonoco: a cura di Fausto Nicolini. Bari: Laterza. (Coleção Scrittori d'Italia.)

D'ORSI, A. 1985. La rivoluzione antibolscevica: fascismo, classi, ideologie (1917-1922). Milano: Franco Angeli. 
D'ORSI, A.; CHIAROTTO, F. 2012. Introduzione. In: GRAMSCI, A. Scritti della libertà: 1910-1926. Torino: Riuniti.

FIORI, G. 2003. Vita di Antonio Gramsci. Nuoro: Ilisso.

GENTILE, G. 1937 [1912]. L'atto del pensare como atto puro. Firenze:

Sansoni.

GRAMSCI, A. 1973. Scritti politici. Roma: Riuniti. 1975. Quaderni del carcere. Torino: Giulio Einaudi. 4 v. 1980. Cronache torinesi: 1913-1917. Torino: Giulio Einaudi. 1982. La città futura: 1917-1918. Torino: Giulio Einaudi. . 1984. Il nostro Marx. Torino: Giulio Einaudi. 2009. Epistolario I: gennaio 1906 - dicembre 1922. Roma: Istituto

della Enciclopedia Italiana. 2010. Cronache teatrali: 1915-1920. Torino: Nino Aragno.

IL NUOVO colpo di Stato in Russia. 1917. La Stampa, Torino, p. 1, 10 nov. 1917.

KERENSKI rassegna le dimissioni per l'impossibilità di ricostituire il Governo. 1917. La Stampa, Torino, p. 4, 5 ago. 1917.

MARX, K. 2013. O capital: crítica da economia política. São Paulo: Boitempo. (Livro I: O processo de produção do capital).

MISSIROLI, M. 1914. La monarchia socialista: estrema destra. Bari: Laterza.

PAGGI, L. 1970. Nella crisi del socialismo italiano. Roma: Riuniti.

(Série Gramsci e il moderno principe, v. 1).

RAPONE, L. 2011. Cinque anni che paiono secoli: Antonio Gramsci da socialismo al comunismo: 1914-1919. Roma: Carocci.

ROLLAND, R. 1953. L'esprit libre. Paris: Albin Michel.

SALVEMINI, G. 1905. La rivoluzione francese: 1788-1792. Milano: Signorelli \& Palestrini.

SOREL, G. 2013 [1908]. Réflexions sur la violence. Genève; Paris: Entremonde.

SPRIANO, P. 1972. Storia di Torino operaia e socialista: da De Amicis a Gramsci. Torino: Giulio Einaudi.

TERRACINI, U. 1976. Ricordi e riflessioni di un rivoluzionario professionale. Belfagor: Rassegna di varia umanità, v. 31, n. 3, pp. 249-266. TREVES, C.; TURATI, F. 1917. Proletariato e resistenza. Critica Sociale, v. 27, n. 21, pp. 266-267.

TURATI, F. 1917. Per il nuovo regime in Russia. Atti parlamentari, Legislatura XXIV, $1^{\text {a }}$ sessione, Discussione della Camera dei Deputati, Tornata del 23 mar. 1917, pp. 13375-13377. 


\section{D)}

\section{ANTONIO GRAMSCI, A CULTURA SOCIALISTA E A REVOLUÇÃO RUSSA}

DANIELA XAVIER HAJ MUSSI

ALVARO BIANCHI

Resumo: Neste texto recuperam-se os artigos jornalísticos de Antonio Gramsci publicados entre 1915 e 1917, em que é abordado o tema da revolução. Para isso, reconstroem-se as análises gramscianas em perspectiva histórica, retomando a Revolução Francesa como paradigma e as mudanças de ênfase no contexto de outra revolução em curso, na Rússia. Evidencia-se o percurso analítico por meio do qual Gramsci modifica sua forma de pensar o problema cultural e político da revolução, em particular a reflexão sobre o uso da força militar com fins revolucionários. Conclui-se que Gramsci, neste período, inicia o desenvolvimento de um pensamento original sobre cultura e política, abrindo caminho para o que seria mais tarde sua elaboração sobre o conceito de hegemonia.

Palavras-chave: Antonio Gramsci; Revolução Russa; Cultura; Política.

\section{ANTONIO GRAMISCI, SOCIALIST CULTURE AND RUSSIAN REVOLUTION}

Abstract: This article retrieves Antonio Gramsci's newspaper articles published between 1915 and 1917 where the theme of the revolution appears. To do so, it reconstructs the Gramscian analysis in historical perspective, retaking the French Revolution as a paradigm and the changes of emphasis in the context of a new revolution under way, now in Russia. It shows the analytical course through which Gramsci modifies his way of thinking the cultural and political problem of the revolution, in particular the reflection on the use of military force for revolutionary purposes. It concludes 
that Gramsci, in this period, begins the development of an original thought about culture and politics, opening the way to what would later be his elaboration on the concept of hegemony.

Keywords: Antonio Gramsci; Russian Revolution; Culture; Politics.

Recebido: 01/05/2017 Aprovado: 04/09/2017 